\title{
Вплив політравми на динаміку показників ліпідної пероксидації та ан- тиоксидантного захисту тканини кіркового шару нирки у тварин із хронічним гепатитом у ранній період травматичної хвороби
}

\author{
R. V. BLYZNIUK, A. A. HUDYMA, R. I. TSYTSYURA \\ SHEI "Ternopil State Medical University by I. Ya. Horbachevsky"
}

\begin{abstract}
INFLUENCE OF POLYTRAUMA ON THE DYNAMICS OF LIPID PEROXIDATION AND ANTIOXIDANT PROTECTION INDICES OF TISSUES OF CORTICAL KIDNEY IN ANIMALS WITH CHRONIC HEPATITIS IN THE EARLY PERIOD OF TRAUMATIC DISEASE
\end{abstract}

\begin{abstract}
В умовах політравми, модельованої на тлі хронічного гепатиту в ранній період травматичної хвороби, в кірковому шарі нирок відмічається більша інтенсифікація ліпідної пероксидації, яка проявляється збільшенням вмісту ТБК-активних продуктів ПОЛ, порівняно з контрольною групою і групою тварин без супутньої патології печінки. У кірковому шарі нирки на тлі політравми і хронічного гепатиту відмічаються порушення ферментативної ланки антиоксидантного захисту, що проявляється значним зростанням активності СОД до 3-ї доби з наступним зниженням до 7-ї, поступовим зниженням активності каталази та величини АПІ до 7-ї доби, порівняно з тваринами без хронічного гепатиту, що вказує на більше виснаження в цей термін механізмів антиоксидантного захисту в тканині нирки.

In the context of polytrauma, modeled on the background of chronic hepatitis in the early period of traumatic disease in renal cortex there is great intensification of lipid peroxidation, which manifests an increase in the content of TBA-reactive products of lipid peroxidation, compared with the control group and animals without concomitant liver pathology. The cortical layer of the kidneys on the background of polytrauma and chronic hepatitis there were observed violations of the enzymatic link of antioxidant defense, manifested a significant increase in SOD activity to 3 days, followed by a decrease to 7 , a gradual decrease in the activity of catalase and the value of the API for 7 days, compared with the animals without chronic hepatitis, it is indicating a greater depletion in this term antioxidant defense mechanisms in renal tissue.
\end{abstract}

Постановка проблеми і аналіз останніх досліджень та публікацій. Проблема травматизму $є$ актуальною в Україні та світі. У структурі травматизму останнім часом відмічається невпинна тенденція до зростання частоти поєднаної травми, яка складає 23,5-85,0 \% і характеризується тяжкими ускладненнями та високою летальністю [16]. В цих умовах розвивається травматична хвороба, проявом якої $є$ сукупність системних порушень із ураженням органів і систем, віддалених від місця безпосередньої травми. Важливе значення в патогенезі травматичної хвороби має розвиток поліорганної дисфункції і недостатності [1]. В цих умовах печінка і нирки як основні органи детоксикації та виділення $€$ постійними органами-мішенями в умовах тяжкої скелетної травми.

Останніми роками значно збільшилася частота хронічних захворювань печінки. Серед їх причин провідне місце займає зростання інфікованості ві- русними гепатитами, погіршання екологічної обстановки, безконтрольне вживання алкоголю та медикаментів. У даний час, за даними ВООЗ, на хронічний гепатит С в світі хворіє понад 200 млн людей, тобто близько 3 \% населення планети $[10,11]$. Тому виникнення тяжкої травми на тлі супутнього хронічного гепатиту стає важливою медичною проблемою.

В умовах хронічних дифузних захворювань печінки вторинно виникає зниження ефективності механізмів, які забезпечують водно-сольовий гомеостаз, і залежить від ступеня тяжкості патологічних змін паренхіми печінки [5]. Разом з тим, несприятливий прогноз розвитку патології печінки зумовлений у тому числі й розвитком ниркової недостатності [15]. У зв'язку з цим, патогенні механізми ураження нирки на тлі хронічного гепатиту та тяжкої травми потребують поглибленого вивчення.

Відомо, що інтенсифікація ліпопероксидації та порушення антиоксидантного захисту належать до 
ключових патогенетичних механізмів травматичної хвороби [4]. Однак їх динаміка у тканині нирки в умовах політравми і хронічного гепатиту вивчена недостатньо.

Мета роботи: з'ясувати вплив політравми на динаміку показників ліпідної пероксидації та антиоксидантного захисту тканини кіркового шару нирки у тварин із хронічним гепатитом у ранній період травматичної хвороби.

Матеріали і методи. Експерименти виконано на 98 нелінійних білих щурах-самцях масою 180-200 г. У першій дослідній групі моделювали хронічний гепатит за методом Siegers C. P. et al. (1982) шляхом внутрішньоочеревинного введення 50 \% олійного розчину тетрахлорметану в дозі 0,2 мл•кг ${ }^{-1}$ два рази на тиждень протягом чотирьох тижнів із заміною питної води 5 \% розчином етанолу [13]. У другій дослідній групі замість розчину тетрахлорметану вводили фізіологічний розчин в еквівалентній дозі. Через 4 тижні тваринам обох дослідних груп моделювали політравму за методом Секели Т. Я. та Гудими А. А. (2008). Під тіопенталонатрієвим наркозом (40 мг·кГ-1) в асептичних умовах у тварин викликали кровотечу зі стегнової вени (близько 20 \% об’єму циркулюючої крові), яку вводили у паранефральну клітковину з розрахунку 1 мл на 100 г маси тварини. Далі з операційного доступу ламали стегно, рану зашивали [9]. Контрольні групи склали інтактні тварини та тварини із хронічним гепатитом.
Тварин, які вижили, виводили з експерименту в умовах знеболювання методом тотального кровопускання з серця через 1, 3 і 7 діб після нанесення травми. У тварин швидко видаляли нирки й на заморожувальному столику відділяли кірковий шар, у гомогенаті якого визначали вміст ТБК-активних продуктів ПОЛ [2], активність супероксиддисмутази (СОД) [12], каталази [7] та розраховували антиоксидантно-прооксидантний індекс (АПІ) як співвідношення активності каталази до вмісту ТБК-активних продуктів ПОЛ [3].

Для оцінки вірогідності відмінностей між контрольними і дослідними групами статистичну обробку результатів виконано у відділі системних статистичних досліджень університету в програмному пакеті Statsoft STATISTICA.

Результати досліджень та їх обговорення. У тканині кіркового шару нирок (табл. 1) під впливом політравми вміст ТБК-активних продуктів ПОЛ порівняно з контрольною групою істотно зростав: через 1 добу - у 2,25 раза, через 3 доби - у 3,14 раза, через 7 діб - у 3,29 раза, що виявилося статистично вірогідним $(\mathrm{p}<0,05)$.

На тлі хронічного гепатиту вміст ТБК-активних продуктів ПОЛ у тканині кіркового шару нирок вже у контрольній групі суттєво переважав у групі тварин із хронічним гепатитом (на 30,8 \%, p<0,05). У динаміці політравми показник виявився теж істотно більшим, ніж у контрольній групі: через 1 добу - у 2,25 раза, через 3 доби - у 3,21 раза, через 7 діб

Таблиця 1. Рівень ліпідної пероксидації та антиоксидантного захисту у тканині кіркового шару нирки в динаміці раннього періоду травматичної хвороби на тлі хронічного гепатиту (M $\pm \mathrm{m})$

\begin{tabular}{|c|c|c|c|c|c|}
\hline \multirow[b]{2}{*}{ Показник } & \multirow[b]{2}{*}{ Дослідна група } & \multirow[b]{2}{*}{$\begin{array}{c}\text { Контроль } \\
(\mathrm{n}=6 / 7)\end{array}$} & \multicolumn{3}{|c|}{ Політравма } \\
\hline & & & $\begin{array}{c}\text { 1-ша доба } \\
\text { (n=9/10) }\end{array}$ & $\begin{array}{c}\text { 3-тя доба } \\
(n=8 / 9)\end{array}$ & $\begin{array}{c}\text { 7-ма доба } \\
\mathrm{n}=8 / 9)\end{array}$ \\
\hline \multirow{2}{*}{$\begin{array}{l}\text { МДА, } \\
\text { мкмоль } \Gamma^{-1}\end{array}$} & Без гепатиту & $1,04 \pm 0,04$ & $1,29 \pm 0,03^{*}$ & $2,32 \pm 0,10^{* 1}$ & $3,36 \pm 0,15^{* 1,3}$ \\
\hline & Хронічний гепатит & $1,36 \pm 0,05$ & $3,06 \pm 0,14^{*}$ & $4,37 \pm 0,20^{* 1}$ & $4,48 \pm 0,25^{* 1}$ \\
\hline \multicolumn{2}{|r|}{$\mathrm{p}$} & $<0,05$ & $<0,05$ & $<0,05$ & $<0,05$ \\
\hline \multirow{2}{*}{$\begin{array}{l}\text { СОД, } \\
\text { ум. од. } \text { кг }^{-1}\end{array}$} & Без гепатиту & $0,098 \pm 0,006$ & $0,105 \pm 0,007$ & $0,109 \pm 0,007$ & $0,215 \pm 0,011^{* 1,3}$ \\
\hline & Хронічний гепатит & $0,112 \pm 0,006$ & $0,153 \pm 0,006^{*}$ & $0,364 \pm 0,019^{* 1}$ & $0,250 \pm 0,014^{* 1,3}$ \\
\hline \multicolumn{2}{|r|}{$\mathrm{p}$} & $>0,05$ & $<0,05$ & $<0,05$ & $>0,05$ \\
\hline \multirow{2}{*}{$\begin{array}{l}\text { Каталаза, } \\
\text { мккат•кг-1 }\end{array}$} & Без гепатиту & $0,52 \pm 0,02$ & $0,39 \pm 0,02^{*}$ & $0,30 \pm 0,01^{* 1}$ & $0,39 \pm 0,03^{* 3}$ \\
\hline & Хронічний гепатит & $0,41 \pm 0,03$ & $0,34 \pm 0,03$ & $0,32 \pm 0,02^{*}$ & $0,20 \pm 0,02^{* 1,3}$ \\
\hline \multicolumn{2}{|r|}{$\mathrm{p}$} & $<0,05$ & $>0,05$ & $>0,05$ & $<0,05$ \\
\hline \multirow{2}{*}{$\begin{array}{l}\text { АПІ, } \\
\text { ум. од. }\end{array}$} & Без гепатиту & $0,51 \pm 0,03$ & $0,30 \pm 0,02^{*}$ & $0,13 \pm 0,01^{* 1}$ & $0,12 \pm 0,01^{* 1}$ \\
\hline & Хронічний гепатит & $0,30 \pm 0,02$ & $0,11 \pm 0,01^{*}$ & $0,07 \pm 0,01^{* 1}$ & $0,046 \pm 0,004^{* 1,3}$ \\
\hline \multicolumn{2}{|r|}{$\mathrm{p}$} & $<0,05$ & $<0,05$ & $<0,05$ & $<0,05$ \\
\hline
\end{tabular}

Примітка. * - відмінності стосовно контрольної групи статистично вірогідні (р<0,05); р - вірогідність відмінностей між групами без гепатиту та із хронічним гепатитом; ${ }^{1,3}$ - показники стосовно 1 i 3 діб спостереження статистично вірогідні (р<0,05); $\mathrm{n}-\mathrm{y}$ чисельнику: кількість тварин у дослідній групі без гепатиту, у знаменнику: із хронічним гепатитом. 
- у 3,29 раза $(\mathrm{p}<0,05)$. Слід відмітити, що у всі терміни спостереження вміст у тканині кіркового шару нирок ТБК-активних продуктів ПОЛ на тлі політравми суттєво перевищував групу тварин без хронічного гепатиту: через 1 добу - у 2,37 раза, через 3 доби - на 88,4 \%, через 7 діб - на 33,3 \% (p<0,05). Аналіз динаміки цього показника у травмованих тварин із хронічним гепатитом показав, що через 3 доби він досягав максимальної величини, що виявилося статистично вірогідним порівняно 31 добою $(\mathrm{p}<0,05)$, і залишався на такому ж рівні й через 7 діб.

Активність СОД у кірковому шарі нирки в умовах політравми збільшувалася, однак результат ставав статистично вірогідним тільки через 7 діб після нанесення травми (у 2,19 раза, $\mathrm{p}<0,05)$. На тлі хронічного гепатиту в контрольній групі активність СОД кіркового шару нирки практично не відрізнялася від аналогічного показника тварин без хронічного гепатиту $(\mathrm{p}>0,05)$. У всі терміни посттравматичного періоду показник виявився істотно більшим, ніж у контрольній групі: через 1 добу - на 36,6 \%, через 3 доби - у 3,25 раза, через 7 діб - у 2,23 раза $(\mathrm{p}<0,05)$. Аналогічно показник був більшим і порівняно $з$ тваринами без хронічного гепатиту (відповідно, на 45,7, 233,9 і 16,3 \%, p<0,05). Аналізуючи динаміку досліджуваного показника в посттравматичному періоді, з'ясувалося, що у тварин без хронічного гепатиту показник через 7 діб досягав максимальної величини й істотно перевищував рівень 1 і 3 діб $(\mathrm{p}<0,05)$. На тлі хронічного гепатиту він змінювався фазово, досягаючи максимальної величини через 3 доби, що виявилося статистично вірогідним стосовно 1 доби $(\mathrm{p}<0,05)$, з наступним зниженням через 7 діб ( $<0,05$ стосовно 1 і 3 діб).

Активність каталази кіркового шару нирки під впливом політравми знижувалася порівняно із контрольною групою: через 1 добу - на 25,0 \%, через 3 доби - на 42,3 \%, через 7 діб - на 25,0\%. В усі терміни спостереження результат виявився статистично вірогідним $(\mathrm{p}<0,05)$. В умовах хронічного гепатиту активність каталази кіркового шару нирки вже у контрольній групі була істотно меншою, ніж у групі порівняння (на 21,1 \%, p<0,05). Через 1 добу показник практично не відрізнявся від контролю (р>0,05), проте через 3 і 7 діб він знижувався (відповідно, на 22,0 і 51,2 \%, p<0,05). Порівнюючи дослідні групи між собою, з’ясувалося, що через 1 і 3 доби активність каталази кіркового шару нирки в обох групах була майже однаковою (p>0,05), проте через 7 діб на тлі хронічного гепатиту вона ставала нижчою (на 48,7 \%, p $<0,05)$. Аналіз динаміки досліджуваного показника показав, що у тварин без хронічного гепатиту активність каталази ткани- ни кіркового шару нирки досягала мінімальної величини через 3 доби, що було істотно менше, ніж через 1 добу $(\mathrm{p}<0,05)$. Через 7 діб показник збільшувався й статистично вірогідно ставав вищим від рівня 3-ї доби $(\mathrm{p}<0,05)$. На тлі хронічного гепатиту показник поступово знижувався до 7-ї доби. В цей термін він виявився суттєво нижчим, ніж через 1 i 3 доби ( $<<0,05)$.

Величина АПІ внаслідок політравми значно зменшувалася: через 1 добу - на 41,2 \%, через 3 доби - на 74,5 \%, через 7 діб - на 76,5 \% $(\mathrm{p}<0,05)$. В умовах хронічного гепатиту в контрольній групі показник виявився істотно нижчим, ніж у групі порівняння (на 41,2 \%, p<0,05). Аналогічно він був нижчим стосовно контролю і в посттравматичному періоді (відповідно, на 63,3, 76,7 і 84,7 \%, $\mathrm{p}<0,05)$. Звертає на себе увагу той факт, що в усі терміни спостереження величина АПІ у тварин із хронічним гепатитом виявилася вірогідно нижчою, ніж у тварин без хронічного гепатиту (відповідно, на 63,3, 46,2 і 61,7 \%, p<0,05). Динаміка досліджуваного показника засвідчує його різке зниження у групі тварин без хронічного гепатиту до 3-ї доби 3 наступною стабілізацією до 7-ї. У ці терміни показник був статистично вірогідно меншим, ніж через 1 добу $(\mathrm{p}<0,05)$. В умовах хронічного гепатиту показник поступово знижувався з 1-ї до 7-ї доби, причому через 7 діб він був істотно меншим, ніж через 1 i 3 доби $(\mathrm{p}<0,05)$.

Таким чином, в умовах політравми в ранній період травматичної хвороби спостерігається інтенсифікація ліпідної пероксидації в кірковому шарі нирок, яка проявляється збільшенням вмісту ТБКактивних продуктів ПОЛ порівняно з контрольною групою. На тлі супутнього хронічного гепатиту величина цього показника вже у контрольній групі $€$ більшою, ніж у тварин без хронічного гепатиту. На тлі політравми і хронічного гепатиту показник продовжує залишатися істотно більшим, ніж у групі тварин без хронічного гепатиту. Отже, в умовах поєднаної патології інтенсифікація ліпідної пероксидації є більшою. Очевидно, має місце безпосередній вплив патогенних механізмів травми на тканину нирок, що відмічено у роботах окремих авторів [8, 14], а також результат одночасного ураження нирок в умовах хронічного гепатиту. Отже, в умовах гепаторенального синдрому тяжкість ураження нирки внаслідок політравми є більшою.

У кірковому шарі нирки на тлі політравми відмічаються порушення ферментативної ланки антиоксидантного захисту, що проявляється поступовим збільшенням активності СОД до 7-ї доби, зниженням активності каталази до 3-ї доби з наступним підвищенням до 7-ї та значним падінням 
величини АПІ, що вказує на домінування до 7-ї доби саногенних механізмів в умовах політравми. Подібна реакція закономірна в умовах досліджуваної моделі політравми [6]. На тлі хронічного гепатиту порушення більші. Характерною їх особливістю $\epsilon$ значне зростання активності СОД до 3-ї доби з наступним зниженням до 7-ї, поступове зниження активності каталази та величини АПІ до 7-ї доби, що вказує на більше виснаження в цей термін механізмів антиоксидантного захисту в тканині нирки.

Враховуючи, що в кірковому шарі нирки в основному зосереджені ниркові клубочки, а на тлі інтенсифікації ПОЛ передусім страждають клітинні мембрани, можна припустити, що в умовах хронічного гепатиту і політравми можна очікувати більших і функціональних порушень нирки, що потребує свого подальшого дослідження.

\section{СПИСОК ЛІТЕРАТУРИ}

1. Александрова О. С. Факторный анализ проявлений полиорганной недостаточности и их роли в наступлении неблагоприятного исхода у пострадавших с сочетанной травмой живота / О. С. Александрова, Ю. М. Гаин // Медицинский журнал. - 2009. - № 2. - С. 19-23.

2. Андреева Л. И. Модификация метода определения перекисей липидов в тесте с тиобарбитуровой кислотой / Л. И. Андреева, Л. А. Кожемякин, А. А. Кишкун // Лаб. дело. - 1988. - № 11. - С. 41-43.

3. Антиоксидантно-прооксидантний індекс сироватки крові щурів з експериментальним стоматитом і його корекція зубними еліксирами / А. П. Левицький, В. М. Почтар, О. А. Макаренко, Л. І. Гридіна // Одеський мед. журн. - 2006. - № 1. - С. 22-25.

4. Волотовська Н. В. Динаміка показників вільнорадикального окислення і антиоксидантного захисту тканин печінки в умовах політравми / Н. В. Волотовська // Медична хімія. 2011. - Т. 13, № 4 (49). - С. 224.

5. Гончарова Л. В. Осморегулирующая функция почек при токсических нефропатиях, индуцированных четыреххлористым углеродом / Л. В. Гончарова, І. А. Кузьменко // Актуальні проблеми транспортної медицини. - 2006. - № 2 (4). - С. 43-47.

6. Динаміка адаптаційних можливостей організму лабораторних тварин на різних моделях механічної травми / I. Р. Мисула, А. А. Гудима, Т. Я. Секела, О. Я. Зятковська // VII читання ім. В. В. Підвисоцького, 22-23 травня 2008 р. : бюлетень. - Одеса, 2008. - С. 41-42.

7. Королюк М. А. Метод определения активности каталазы / М. А. Королюк, Л. И. Иванова, И. Г. Майорова, В. Е. Токарев // Лабораторное дело. - 1988. - № 1. - С. 16-19.

8. Мерлєв Д. І. Особливості антиоксидантно-прооксидантного стану кіркового шару нирок в умовах скелетної, черепно-мозкової
Висновки. 1. В умовах політравми, модельованої на тлі хронічного гепатиту в ранній період травматичної хвороби, в кірковому шарі нирок відмічається більша інтенсифікація ліпідної пероксидації, якапроявляється збільшенням вмісту ТБК-активних продуктів ПОЛ порівняно з контрольною групою і групою тварин без супутньої патології печінки.

2. У кірковому шарі нирки на тлі політравми і хронічного гепатиту відмічаються порушення ферментативної ланки антиоксидантного захисту, що проявляється значним зростанням активності СОД до 3-ї доби з наступним зниженням до 7-ї, поступовим зниженням активності каталази та величини АПІ до 7-ї доби, порівняно з тваринами без хронічного гепатиту, що вказує на більше виснаження в цей термін механізмів антиоксидантного захисту в тканині нирки.

травм та їх поєднання / Д. І. Мерлєв, А. А. Гудима // Здобутки клініч. і експерим. медицини. - 2013. - № 2. - С. 140-142.

9. Пат. на корисну модель 30028 Україна МІЖ 2006 G 09 В 23/00. Спосіб моделювання політравми / Т. Я. Секела, А. А. Гудима (Україна) ; заявник і патентовласник Тернопільський мед. університет. - № U 200710471 ; заявл. 21.09.2007 ; опубл. 11.2.08; Бюл. № 3-4.

10. Сгахі А. Клинические рекомендации EALS: ведение больных с инфекцией, вызванной вирусом гепатита C / A. Сгахі // BEST CLINICAL PRACTICE. Русское издание. 2011. - Вып. 5. - С. 13-37.

11. Федорченко С. В. Хроническая HCV-инфекция : монография / С. В. Федорченко. - К. : Медицина, 2010. - 272 с.

12. Чевари С. Роль супероксиддисмутазы в окислительных процессах клетки и метод определения ее в биологических материалах / С. Чевари, И. Чаба, Й. Сокей // Лаб. дело. - 1985. - № 11. - С. 678-681.

13. Effects of dithiocarb and (+)cyanidanol-3 on the $\mathrm{CCL}_{4}$ alcohol induced fibrosis of rat liver / C. P. Siegers, V. Voipel, G. Schel [et al.] // Connective Tissue Norn. and Fibrotis. Hum. Liver. Stuttgart. New-York. - 1982. - Vol. 3. - P. 244-245.

14. Merlev D. The peculiarities of antioxidant-prooxidant balance of kidney's papillary layer in skeletal and craniocerebral injuries and their combinations [Electronic resourse] / D. Merlev, A. Gudyma // Journal of Health Sciences. - 2014. - Vol. 4, N 1. - P. 134-144. - Available from : http://journal.rsw.edu.pl/index.php/JHS/article/view/508.

15. Moreau R. Hepatorenal syndrome - definitions and diagnosis / R. Moreau, D. Lebrec // Alimentary Pharmacology \& Therapeutics. - 2004. - Vol. 20. - P. 24-28.

16. World report on road traffic injury prevention / [M. Peden, R. Scurfield, D. Sleet et al.]. - Geneva, Switzerland: World Health Organization, 2004. 